\title{
Evaluation of an Unsuccessful Brook Trout Electrofishing Removal Project in a Small Rocky Mountain Stream
}

\author{
Kevin A. Meyer,* James A. Lamansky, JR., And Daniel J. Schill \\ Idaho Department of Fish and Game, 1414 East Locust Lane, Nampa, Idaho 83686, USA
}

\begin{abstract}
In the western United States, exotic brook trout Salvelinus fontinalis frequently have a deleterious effect on native salmonids, and biologists often attempt to remove brook trout from streams by means of electrofishing. Although the success of such projects typically is low, few studies have assessed the underlying mechanisms of failure, especially in terms of compensatory responses. A multiagency watershed advisory group (WAG) conducted a 3-year removal project to reduce brook trout and enhance native salmonids in $7.8 \mathrm{~km}$ of a southwestern Idaho stream. We evaluated the costs and success of their project in suppressing brook trout and looked for brook trout compensatory responses, such as decreased natural mortality, increased growth, increased fecundity at length, and earlier maturation. The total number of brook trout removed was 1,401 in 1998, 1,241 in 1999, and 890 in 2000; removal constituted an estimated $88 \%$ of the total number of brook trout in the stream in 1999 and $79 \%$ in 2000. Although abundance of age-1 and older brook trout declined slightly during and after the removals, abundance of age- 0 brook trout increased $789 \%$ in the entire stream 2 years after the removals ceased. Total annual survival rate for age- 2 and older brook trout did not decrease during the removals, and the removals failed to produce an increase in the abundance of native redband trout Oncorhynchus mykiss gairdneri. Lack of a meaningful decline and unchanged total mortality for older brook trout during the removals suggest that a compensatory response occurred in the brook trout population via reduced natural mortality, which offset the removal of large numbers of brook trout. Although we applaud WAG personnel for their goal of enhancing native salmonids by suppressing brook trout via electrofishing removal, we conclude that their efforts were unsuccessful and suggest that similar future projects elsewhere over such large stream lengths would be costly, quixotic enterprises.
\end{abstract}

Introduced fish species that establish self-sustaining populations threaten the long-term persistence of native fishes (Moyle 1986; Allan and Flecker 1993; Rahel 2000). A classic example is the brook trout Salvelinus fontinalis, which has been introduced since the late 1800 s to diversify or supplement sportfishing opportunities. Brook trout have become widely established in every state in the western United States (Fuller et al. 1999), usually to the detriment of native salmonids (Krueger and May 1991; Young 1995; Levin et al. 2002; see review in Dunham et al. 2002). The ability of brook trout to displace native salmonids is evident, but the mechanisms for their success remain relatively unknown (Fausch 1988, 1989; Griffith 1988; but see Peterson et al. 2004a).

Because of these detrimental effects, biologists have focused their efforts on removing brook trout for conservation and restoration of native salmonids. The most common methods for removing nonnative, stream-dwelling salmonids have been electrofishing (e.g., Moore et al. 1983; Thompson and Rahel 1996; Kulp and Moore 2000; Shepard et al. 2002) and

\footnotetext{
* Corresponding author: kmeyer@idfg.state.id.us
}

Received July 14, 2005; accepted January 26, 2006 Published online November 9, 2006 toxicants (e.g., Phinney 1975; Gresswell 1991), although selective angling (Larson et al. 1986; Paul et al. 2003) and trapping (Young et al. 2003) have been used as well. In general, removal projects have met with little success. Meronek et al. (1996) reviewed 250 fish control projects and found that the goals of reducing or eliminating undesirable fish species were met in less than $50 \%$ of these projects. Nevertheless, the lack of alternatives to removal and the need to contain exotics such as brook trout compel many biologists to continue implementing fish control projects (Finlayson et al. 2005).

Because toxicants (e.g., rotenone and antimycin) kill nontarget species, biologists often view electrofishing as a more desirable alternative for fish removal. However, electrofishing has many of its own shortcomings. First, complete removal of the target species is difficult. Thompson and Rahel (1996) removed 73$100 \%$ of age- 0 brook trout and $59-100 \%$ of age- 1 and older brook trout from three streams in Wyoming but did not eradicate brook trout from any stream. Others have eradicated nonnative trout but at tremendous cost for very small (e.g., $0.8-3.0 \mathrm{~km}$ ) stream sections (Kulp and Moore 2000; Shepard et al. 2002). Another difficulty is that mobile species, such as brook trout, recolonize rapidly unless a barrier between treated and 
untreated reaches is established. Phinney (1975) found that a stream section treated with rotenone was repopulated by brook trout from upstream within 1 year. Similarly, Peterson et al. (2004a) found that immigration replaced $40-100 \%$ of the adult brook trout removed during the previous year.

Even when barriers are established, suppressed populations of brook trout often recover quickly because they mature earlier than most other salmonids. For example, in an attempt to evaluate growth response, Cooper et al. (1962) treated a stream with rotenone to severely reduce (but not eliminate) the number of brook trout. There was no change in growth rate; instead, brook trout abundance quickly recovered and, within 2 years, was no different than before the treatment (most fish were age 0 or 1 ). Furthermore, any remaining or recolonizing brook trout in a treated section may undergo a compensatory response once the fish population has been reduced (McFadden 1961, 1976), negating some or all of the effects of the removal. The term "compensation" (taken from McFadden 1977) refers to the propensity of populations to exhibit reduced death rates or increased birth rates as a population declines (it can also be the opposite). The effect is to (1) stabilize the population before it is extirpated or (2) restore the population to its original condition (McFadden 1977). In the simplest terms, such changes often stem from a reduction in competition for food or space. Previous studies have indicated that brook trout may compensate for increased exploitation through a variety of methods, including decreased natural mortality (McFadden 1961), increased growth and recruitment (Donald and Alger 1989), and increased age-specific fecundity (Jensen 1971). Because these and other mechanisms are not mutually exclusive and may interact at a variety of life history stages, only a few may be statistically verifiable at any given period of observation (McFadden 1977).

In this paper, we describe an electrofishing removal project that was initiated and conducted by a local watershed advisory group (WAG) in southwestern Idaho. The goal of their project was to eliminate or suppress brook trout in a small stream to protect native salmonids (redband trout Oncorhynchus mykiss gairdneri and bull trout $S$. confluentus) in the stream. We evaluated the costs and success of their project, as there was strong interest in conducting similar removal projects by other biologists in southwestern Idaho. Bull trout were nearly extirpated from this stream by the time this project was initiated (only nine bull trout were captured during this study) and thus were not included in our analysis. We monitored population changes for brook trout and redband trout, as well as changes in the population dynamics of brook trout. Our study objectives were to assess (1) whether 3 years of electrofishing removals by the WAG could eliminate or suppress brook trout and increase abundance of native salmonids in subsequent years and (2) whether brook trout that evaded capture underwent any detectable compensatory responses.

\section{Methods}

The project occurred on Pike's Fork, a second-order tributary in the Boise River drainage that is itself a tributary to the Snake River in southwestern Idaho. In the $7.8-\mathrm{km}$ reach of treated stream, mean summer wetted width was $2.8 \mathrm{~m}$, gradient was $3.0 \%$, and elevation was $1,750 \mathrm{~m}$. The Pike's Fork drainage has been logged extensively, but riparian and stream habitat conditions have remained reasonably unaltered. At the start of this study, Pike's Fork contained brook trout, redband trout, a small population of bull trout, and shorthead sculpin Cottus confusus. Sterile rainbow trout $O$. mykiss (200-300 $\mathrm{mm}$ total length [TL]), readily identifiable by fin erosion, are stocked for angler harvest about $3 \mathrm{~km}$ downstream of the study area.

From 1998 to 2000, brook trout were removed annually by WAG crews during $3 \mathrm{~d}$ in mid-August. Block nets were used to section the stream into 200400-m reaches. Crews of four to eight people performed a two-pass electrofishing removal in each reach with the use of two gas- or battery-powered backpack electrofishing units and several netters with dip nets. Pulsed DC was used; pulses were 3-5 ms, 500-900 V, and $60 \mathrm{~Hz}$. One electrofishing operator with a pair of netters proceeded about $20 \mathrm{~m}$ upstream of the other during a single depletion pass by a crew. The methods used resulted in a four-pass removal effort with limited stream rest between the second and fourth passes, whereas the WAG personnel actually conducting the removal effort considered each of these two-shocker-unit runs a single pass. For this reason, we analyzed their data as such. All brook trout collected were measured (nearest millimeter TL) and weighed (nearest gram), killed by overdose with tricaine methanesulfonate at $250 \mathrm{mg} / \mathrm{L}$, and frozen. Redband trout were measured, weighed, and released in the reach from which they were captured.

In 1998, WAG personnel performed removals in the lower $4.5 \mathrm{~km}$ of stream only but discovered that brook trout resided farther upstream than previously suspected. Subsequently, spot surveys were used to comprehensively determine brook trout distribution; in the remaining 2 years, $7.8 \mathrm{~km}$ of stream were electrofished. Due to flagging project interest by WAG members and associated field personnel shortages in 2000, removals were not as rigorous as in the previous 2 years. Instead, 
two crews of four people (each with two backpack electrofishing units and two netters) were established for each day, and each crew covered one reach at a time. The crews made one or two depletion passes as described for previous years.

Immediately after removal efforts in 1998, the U.S. Forest Service constructed a wire gabion barrier at the bottom of the treated section of stream. The barrier and downstream plunge pool were designed with a minimum jumping pool of $0.6 \mathrm{~m}$ and a vertical drop of $0.5 \mathrm{~m}$ at flood stage and $0.8 \mathrm{~m}$ at low flow. This design was intended to prevent upstream migration by resident brook trout while allowing migratory bull trout (>400 mm TL) to scale the barrier (T. Burton, Bureau of Land Management, personal communication) and recolonize the stream. In 1999, we investigated the effectiveness of the barrier. In a 300-m reach of stream directly below the barrier, 50 brook trout $(150 \mathrm{~mm}$ TL or larger) were marked 4 weeks before the electrofishing removals; none were recaptured during subsequent removals in any of the subsequent years.

Abundance.-Abundance, $95 \%$ confidence intervals (CIs), and capture probability (CP) for each species in each reach were estimated with the maximum likelihood model using the software MicroFish (Van Deventer and Platts 1989). If the lower 95\% confidence limit (CL) was less than the actual number of brook trout captured within a reach, we used the number captured as the lower limit. Because electrofishing is size selective (Reynolds 1996) and because we wished to monitor yearly recruitment success, we estimated abundance separately for age- 0 fish $(<80 \mathrm{~mm}$ TL) and age- 1 and older fish ( $\geq 80 \mathrm{~mm}$ TL). For reaches where only one removal pass was made in 2000, estimates of abundance were made by using data from the multipass reaches to construct a linear relationship between the number of brook trout captured in first passes and subsequent maximum likelihood abundance estimates. From these relationships, we predicted brook trout abundance (and 95\% prediction intervals) for the reaches where only a single removal pass was made (Lobón-Cerviá and Utrilla 1993; Jones and Stockwell 1995; Kruse et al. 1998). Separate regression models were built for brook trout smaller than $80 \mathrm{~mm}$ TL and for those $80 \mathrm{~mm}$ TL and larger. Brook trout removal efficiency within each reach was estimated as the number of removed fish divided by the estimated abundance. The entire stream was sampled by use of the above methodology, and estimates were summed (for abundance and CIs) or averaged (for CP) to produce estimates for the entire stream.

Although CP from multipass removals averaged 0.78 , we realized that this was probably an overestimate (Riley and Fausch 1992; Peterson et al. 2004b;
Rosenberger and Dunham 2005), which would in turn cause underestimation of population abundance and overestimation of removal efficiency (especially for age-0 fish). Estimates of abundance should therefore be considered minimum estimates, and estimates of $\mathrm{CP}$ and removal efficiency should be considered maximum estimates.

In mid-August 2003, we returned to compare abundance and population dynamics of brook trout present after 3 years with no removals to the population in the treatment years. Instead of surveying the entire stream length involved in earlier years, we randomly selected twelve $100-\mathrm{m}$ reaches within this area for multipass electrofishing. Brook trout abundance for the 7.8-km stream was estimated by multiplying the mean abundance per reach by 78 (i.e., the number of $100-\mathrm{m}$ reaches in the treated section of stream). For 2003 estimates, formulas for population totals and CIs were from Scheaffer et al. (1996).

Demographic parameters.-The frozen brook trout were thawed in the laboratory. Sagittal otoliths were removed and stored dry in vials. Scales were removed above the lateral line and posterior to the dorsal fin and stored in envelopes. Because scale readings often underestimate age compared with otolith readings (Beamish and McFarlane 1987), age was estimated primarily by viewing whole otoliths, dry or submersed in saline, with a dissecting microscope using reflected light, transmitted light, or both. In the few instances when otolith age could not be estimated $(n=14)$, we pressed scales on acetate slides with a heat press at a force of $703 \mathrm{~kg} / \mathrm{cm}^{2}$ and at a temperature of $110^{\circ} \mathrm{C}$ for 20-30 s and viewed them with a microfiche reader. We aged a subsample $(n=1,775)$ of brook trout that were captured during the study $(n=3,532)$ and estimated age for the remaining fish with the use of age-length keys (DeVries and Frie 1996). Readers estimating age had no knowledge of fish length during readings. The mean index of average error (Beamish and Fournier 1981) between readers for all aged brook trout was $4.9 \%$. When discrepancies between readers occurred, differences were resolved with additional joint readings, and when discrepancies could not be resolved, results for that fish were discarded. All fish were considered 1 year old when they reached their first January.

Gender and maturity were determined by examination of the gonads. Males were classified as immature if testes were opaque and threadlike or mature if they were large and milky white. Females were classified as immature if the ovaries were small, granular, and translucent or mature if they contained large, welldeveloped eggs that filled much of the abdominal 
cavity (Strange 1996). Eggs were counted from 89 mature females across all years.

Following Robson and Chapman (1961), we estimated total annual survival rate $(S)$ and $95 \%$ CIs with a catch curve analysis. Only age- 2 and older brook trout were fully recruited to the electrofishing gear and useable for survival estimates. Catch curve analysis requires that (1) $S$ is uniform with age and does not change over time, (2) the population is sampled randomly, and (3) recruitment is constant each year. We may have violated assumptions (1) and (3) in the second and third year of our study because the removals may have increased total mortality and decreased recruitment. One method of avoiding the necessity of such assumptions is to track abundance (or catch per unit effort) of particular age-classes through time (Ricker 1975). For comparative survival estimates, we attempted this to the extent possible by apportioning abundance to individual age-classes and dividing the number of fish at age $t$ by the number at age $(t+1)$ when appropriate age structure data were available; however, due to methodological constraints of this study, only seven comparisons could be made. Nevertheless, we believe the use of catch curve analysis was justified for several reasons. First, $S$ for the first year was unaffected by any removals and is therefore unbiased. Second, although recruitment was variable, Allen (1997) showed that if the coefficient of variation $(\mathrm{CV})$ of recruitment is $80 \%$ or less, estimates of $S$ should fall within $\pm 10 \%$. In our study, CV was estimated to be $77.4 \%$ for age- 0 brook trout and $81.0 \%$ for age- 1 brook trout. Third, if the removal efforts were to affect the catch curves in any way, there should have been an increase in the negative slope of the curve, resulting in an increase in total mortality. No such increase would be evidence that the assumption of uniform $S$ with age and time was not violated.

Growth was assessed by calculating the mean length at age (and 95\% CIs) from the age-length keys (DeVries and Frie 1996). Because size at age between years is not independent (i.e., small age- 1 fish in one year may result in small age- 2 fish the following year even if incremental growth does not differ among years), we also compared incremental growth between years to assess removal effects or compensatory responses. Changes in size structure were assessed by comparing cumulative length frequencies with a Kolmogorov-Smirnov goodness-of-fit procedure (the sequential Bonferroni technique was used to correct for multiple inference tests; see Rice 1989). To test for changes in fecundity at length between years, we logtransformed the fecundity data to create a linear relationship with fish length, then used analysis of covariance (ANCOVA) to compare slopes $(\beta)$ and elevations $(\alpha)$ of the regressions between years (Zar 1996). To evaluate sex ratio, we calculated $95 \%$ CIs around the percentage of the population that was female (Fleiss 1981); the CIs that did not overlap 50\% indicated a statistically significant departure from a 50:50 ratio.

We characterized length and age at maturity each year by developing logistic regression models to estimate the length and age at which the probability of being mature was 0.50 (termed maturity transition points [MTPs]; see Meyer et al. 2003). Each fish was considered a sample unit, and a binary dependent variable was used for maturity (i.e., $0=$ immature, $1=$ mature) and was related to the independent variables fish length and fish age. Separate estimates were developed for males and females because males tended to mature at a smaller size than females and because selection forces for size at maturity differ between sexes (Roff 1992). We calculated 95\% CIs around the length- and age-based MTPs and compared estimates between years to assess whether any compensatory responses occurred.

\section{Results}

In 1998, 1,401 brook trout were removed from Pike's Fork; 1,241 brook trout were removed in 1999, and 890 were removed in 2000. These removals constituted $88 \%$ of the estimated number of brook trout present in 1999 and $79 \%$ in 2000; a similar estimate was not possible for 1998 because the entire stream was not treated. Personnel expenditure totaled 210 person-days for electrofishing removals over the duration of the project and did not include time required for planning, coordination, or barrier installation.

\section{Abundance}

Because the upper reaches were not treated in 1998, abundance between all years could be compared only for the lower $4.5 \mathrm{~km}$ of stream. In this portion of the stream, abundance of age- 1 and older brook trout did not decrease from August 1998 to August 1999, despite the removal of most of the brook trout estimated to be present in that section (Table 1). However, abundance decreased significantly in 2000 and 2003 relative to 1998 (Figure 1). Abundance of age-0 brook trout decreased significantly from 1998 to 1999 and remained low in 2000; however, by 2003 age-0 abundance had rebounded (Table 2). For the entire $7.8 \mathrm{~km}$ of stream, age-1 and older brook trout apparently decreased markedly, but in 2003 an estimated 655 fish remained. Abundance of age-0 brook trout was low in 1999 and 2000, but after 2 years with no removals the abundance increased to 1,832 fish.

Removal efficiencies in 1998 were estimated to be 
TABLE 1.-Estimated total abundance (with lower and upper 95\% confidence limits [CLs]), capture probabilities (CPs), and removal efficiencies (REs) for brook trout captured in Pike's Fork, Idaho, during August backpack electrofishing surveys, 19982003; blank cells indicate parameters or years where results could not be estimated.

\begin{tabular}{|c|c|c|c|c|c|c|c|c|c|c|}
\hline \multirow[b]{3}{*}{ Year } & \multicolumn{5}{|c|}{ Lower $4.8 \mathrm{~km}$ of stream } & \multicolumn{5}{|c|}{ Entire $7.8-\mathrm{km}$ reach } \\
\hline & \multicolumn{3}{|c|}{ Total abundance } & \multirow[b]{2}{*}{$\begin{array}{l}\text { Mean } \\
\text { CP }\end{array}$} & \multirow[b]{2}{*}{$\begin{array}{c}\text { Estimated } \\
\text { RE }\end{array}$} & \multicolumn{3}{|c|}{ Total abundance } & \multirow[b]{2}{*}{$\begin{array}{l}\text { Mean } \\
\text { CP }\end{array}$} & \multirow[b]{2}{*}{$\begin{array}{c}\text { Estimated } \\
\text { RE }\end{array}$} \\
\hline & $\begin{array}{c}\text { Lower } \\
95 \% \mathrm{CL}\end{array}$ & Estimate & $\begin{array}{c}\text { Upper } \\
95 \% \text { CL }\end{array}$ & & & $\begin{array}{c}\text { Lower } \\
95 \% \text { CL }\end{array}$ & Estimate & $\begin{array}{c}\text { Upper } \\
95 \% \mathrm{CL}\end{array}$ & & \\
\hline \multicolumn{11}{|c|}{ Age 1 and older } \\
\hline 1998 & 688 & 699 & 725 & 0.83 & 0.98 & & & & & \\
\hline 1999 & 671 & 699 & 773 & 0.82 & 0.96 & 1,127 & 1,180 & 1,312 & 0.81 & 0.96 \\
\hline 2000 & 165 & 207 & 394 & & 0.42 & 510 & 629 & 973 & & 0.81 \\
\hline 2003 & 48 & 100 & 152 & 0.82 & & 376 & 655 & 935 & 0.81 & \\
\hline \multicolumn{11}{|c|}{ Age 0} \\
\hline 1998 & 713 & 796 & 890 & 0.69 & 0.90 & & & & & \\
\hline 1999 & 56 & 110 & 192 & & 0.29 & 114 & 224 & 390 & & 0.51 \\
\hline 2000 & 156 & 198 & 369 & & 0.42 & 380 & 498 & 798 & & 0.76 \\
\hline 2003 & 39 & 517 & 1,157 & 0.62 & & 1,014 & 1,832 & 2,650 & 0.68 & \\
\hline
\end{tabular}

high, but again only the lower portion of the stream was treated. In the 2 years when the entire stream was treated, estimated removal efficiency within each reach averaged $64 \%$ for age- 0 brook trout and $89 \%$ for age- 1 and older brook trout (Table 1).

While brook trout were being removed, there was no consistent increase in abundance of redband trout (Figure 1). Abundance of age-1 and older redband trout remained relatively constant during the removal years, averaging about 1,480 fish. However, by 2003 the abundance decreased to 808 fish. Abundance of age- 0 redband trout increased from 137 fish in 1999 to 799
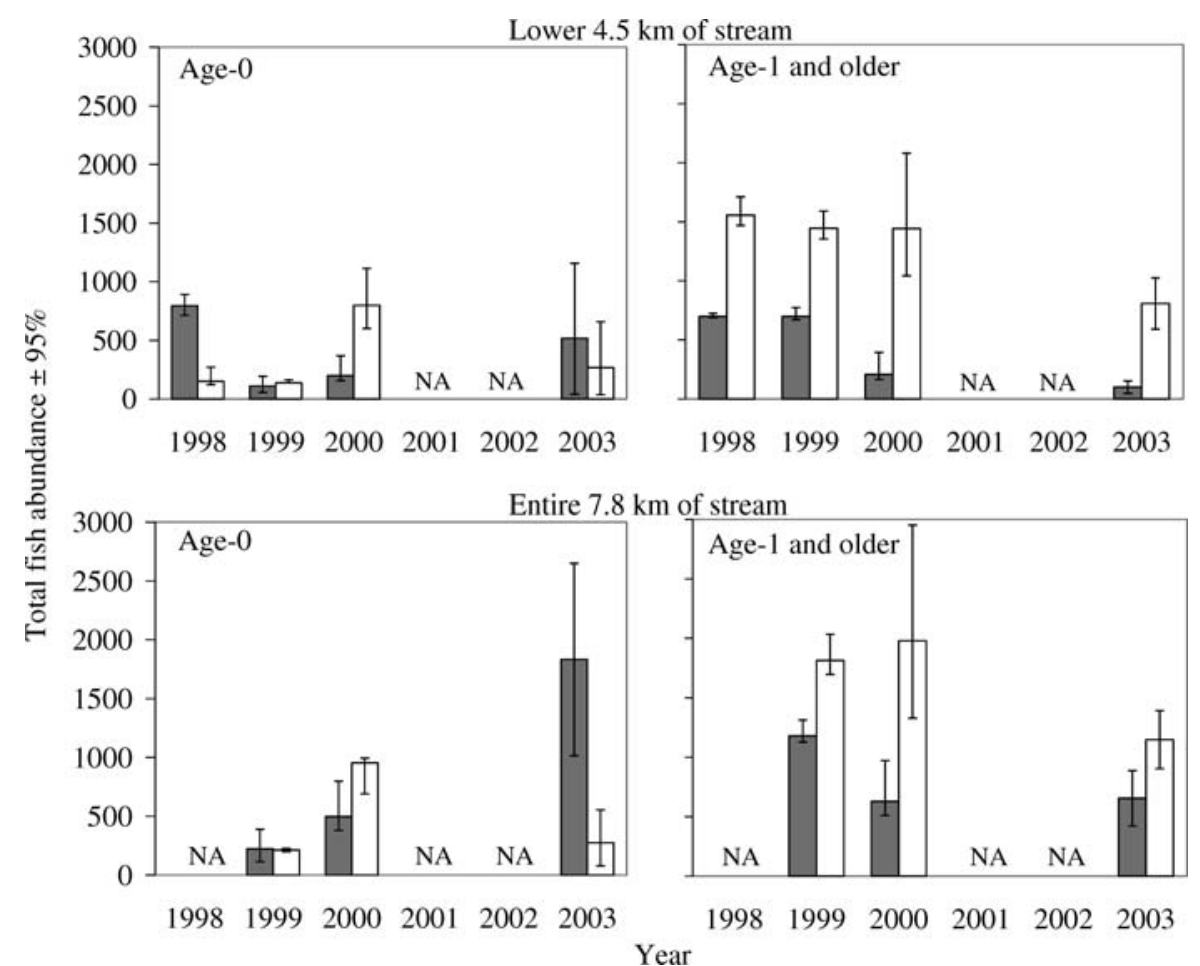

FiguRE 1.-Abundance $( \pm 95 \% \mathrm{CI})$ of nonnative brook trout (shaded) and native redband trout (unshaded) in Pike's Fork, Idaho, upstream of a man-made barrier during 1998-2003. Electrofishing removal of brook trout was conducted in all years except 2001 and 2002. 
TABLE 2.-Estimated total brook trout abundance by stream reach and age-group in Pike's Fork, Idaho, 1998-2003. At age 2, fish apparently became fully recruited to the electrofishing gear (see text) and estimates thus became more reliable. Removal was not conducted in 2001 or 2002. Blank cells indicate years when results could not be estimated.

\begin{tabular}{|c|c|c|c|c|c|c|c|c|c|c|c|c|}
\hline \multirow[b]{2}{*}{ Age } & \multicolumn{4}{|c|}{ Lower $4.5 \mathrm{~km}$} & \multicolumn{4}{|c|}{ Upper $3.3 \mathrm{~km}$} & \multicolumn{4}{|c|}{ Entire $7.8 \mathrm{~km}$} \\
\hline & 1998 & 1999 & 2000 & 2003 & 1998 & 1999 & 2000 & 2003 & 1998 & 1999 & 2000 & 2003 \\
\hline 0 & 796 & 110 & 198 & 517 & & 114 & 300 & 1,315 & & 224 & 498 & 1,832 \\
\hline 1 & 198 & 455 & 106 & 83 & & 227 & 126 & 460 & & 683 & 228 & 543 \\
\hline 2 & 457 & 191 & 81 & 17 & & 200 & 225 & 95 & & 389 & 308 & 112 \\
\hline 3 & 44 & 46 & 20 & 0 & & 49 & 62 & 0 & & 95 & 82 & 0 \\
\hline 4 & 0 & 7 & 0 & 0 & & 5 & 9 & 0 & & 13 & 10 & 0 \\
\hline 5 & 0 & 0 & 0 & 0 & & 0 & 0 & 0 & & 0 & 1 & 0 \\
\hline Total & 1,495 & 809 & 405 & 617 & & 595 & 722 & 1,870 & & 1,404 & 1,127 & 2,487 \\
\hline
\end{tabular}

fish in 2000 , but by 2003 abundance had decreased to levels similar to the pretreatment period.

\section{Demographic Parameters}

Total $S$ for brook trout was low in all years. Based on catch curves (Figure 2 ), $S$ ( $\pm 95 \% \mathrm{CI}$ ) for age-2 and older brook trout was $0.08 \pm 0.02$ in $1998,0.20 \pm$ 0.04 in 1999 , and $0.21 \pm 0.04$ in 2000 . No estimate could be made in 2003 because we did not capture any fish older than age 2. Cohort analysis also supported the fact that $S$ was low. In the lower $4.5 \mathrm{~km}$ of Pike's Fork, $S$ from 1998 to 1999 estimated for individual age-classes was 0.10 for age $2-3$ and 0.16 for age 3-4 (Table 2); when all age-2 and older fish were combined for one estimate, $S$ was 0.11 . Similarly, for the combined data (fish $\geq$ age 2), $S$ from 1999 to 2000 was 0.08 for the lower portion of Pike's Fork, 0.28 for the upper portion, and 0.19 for the entire stream (Table 2). Survival appeared to be higher for age $0-1$ and age

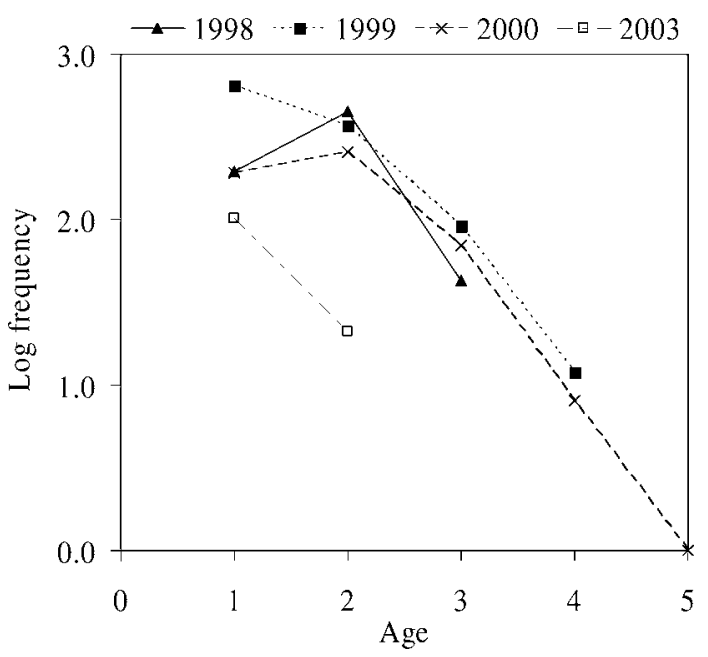

FIGURE 2.-Catch curves for nonnative brook trout removed by electrofishing in Pike's Fork, Idaho, during 1998-2000 and 2003 .
1-2, but because these brook trout were not fully recruited to the sampling gear the estimates were less reliable. We tended to catch older brook trout as the removals continued. The oldest observed age of brook trout within each year was age 3 in 1998, age 4 in 1999, and age 5 in 2000. In 2003, 2 years after cessation of removals, the oldest observed brook trout was age 2 .

Age-2 and younger brook trout comprised 91-100\% of all brook trout present from 1998 to 2003. During all years of the study, only $2 \%$ of the brook trout were age 4 or older. Brook trout growth varied between ageclasses and study years and may have been affected by the removal efforts. For example, age-0 brook trout were significantly larger in 2000 (the year after abundance was lowest) than in other years (Figure 3). Also, age-1-2 brook trout were significantly smaller after the initial removal years but recovered by 2003 . Growth slowed as fish aged, but there were no prominent patterns in incremental growth between years (Figure 3).

Changes in the redband trout and brook trout populations were evident when comparing size structure of fish in Pike's Fork (Figure 4). Brook trout cumulative length frequency was significantly different between all years; the frequency of age-0 brook trout declined from 1998 to $1999(P<0.001)$, rebounded in $2000(P<0.001)$, and increased in $2003(P<0.001)$, when there were few larger brook trout. The first year of removal had little effect on the cumulative length frequency of redband trout, but in 2000 the percentage of redband trout smaller than $150 \mathrm{~mm}$ TL was greater than in previous years $(P<0.001)$. The cumulative length frequency of redband trout in 2003 did not differ from the pretreatment length frequency $(P=0.30)$.

The length-weight relationships were nearly identical between all years (Figure 5). The length-fecundity relationships (Figure 5) also did not differ between years for slope $(P=0.18)$ or elevation $(P=0.13)$, although sample sizes were small for some years and 

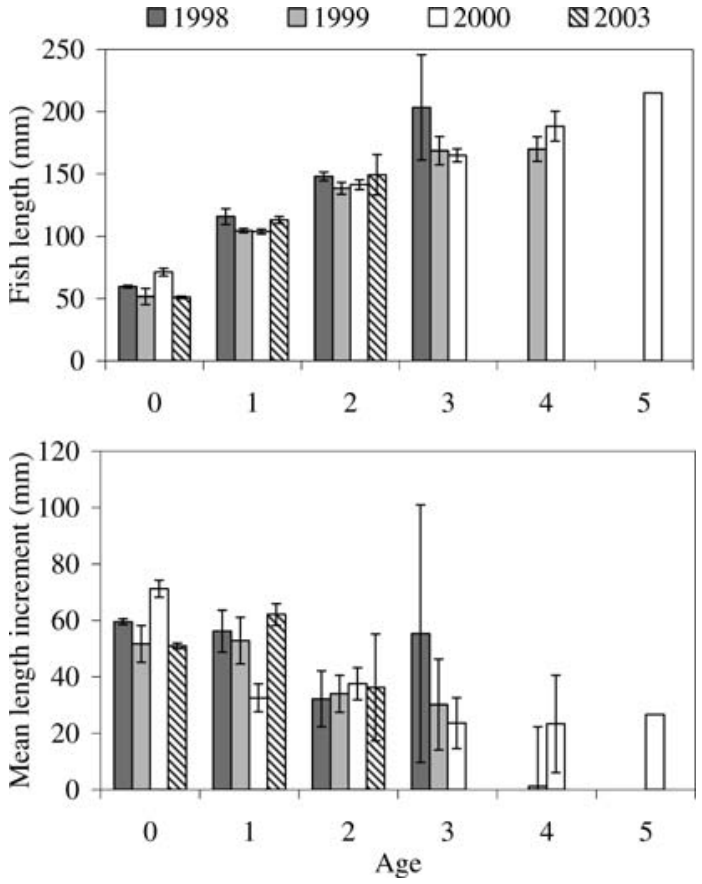

FIGURE 3.-Mean ( $\pm 95 \%$ CI $)$ length at age and length increment for nonnative brook trout removed by electrofishing in Pike's Fork, Idaho, during 1998-2000 and 2003.

the resultant power of this ANCOVA test was low. Of the brook trout whose sex could be determined, females comprised $59 \%$ of the population in 1998, $53 \%$ in $1999,59 \%$ in 2000 , and $50 \%$ in 2003 ; females significantly outnumbered males only in 2000, when the proportion of females was $59 \% \pm 6 \%$.

Length and age at maturity for brook trout changed little over the course of the study. In all years, there was always a higher proportion of mature males than females for each age-class (Figure 6), most notably for ages 1 and 2 . The smallest mature male and female brook trout were both $95 \mathrm{~mm}$ TL, while the largest immature male and female were 157 and $188 \mathrm{~mm}$ TL, respectively. Length-based MTPs averaged $124.5 \mathrm{~mm}$ TL for male brook trout and $147.3 \mathrm{~mm}$ TL for females; CIs did not overlap between genders during any year (Figure 7). Although both male and female brook trout appeared to mature at a slightly smaller size after the removals began, this trend was not statistically significant. Age-based MTP models were less precise than length-based models, but the patterns were the same.

\section{Discussion}

Three years of intensive electrofishing removals appeared to have no long-term effects on the abundance of brook trout in Pike's Fork. Although

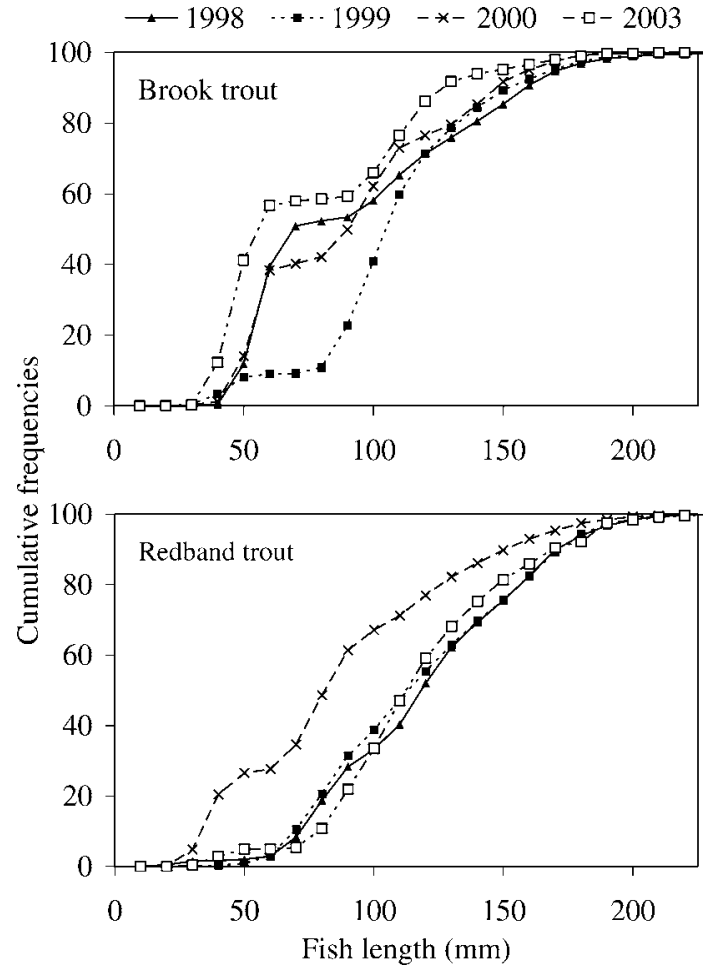

FIGURE 4.-Cumulative length frequencies of nonnative brook trout and native redband trout in Pike's Fork, Idaho, during 1998-2003. Electrofishing removal of brook trout was conducted in all years except 2001 and 2002.

abundance of age-1 and older brook trout declined slightly, abundance of age-0 brook trout increased $789 \%$ in the entire stream 2 years after the removals ceased. Concurrently, the removals produced no increase in redband trout abundance. The lack of a meaningful decline in brook trout abundance coupled with a lack of increase in total mortality of age- 2 and older brook trout during removal treatments suggest that a compensatory response occurred in the brook trout population via reduced natural mortality, which offset the removal of large numbers of brook trout. McFadden (1977) pointed out the logical necessity that if a population is at equilibrium, any increase in mortality (in the present study, "fishing" mortality caused by WAG electrofishing exploitation) must be compensated for in some manner or the population would be extirpated.

Brook trout that avoided exploitation in this study would have experienced much less competition for food and space, but we saw few changes in the brook trout population. We did not observe increased growth in all brook trout age-classes while abundance was lower during removal (age-1-2 growth actually 

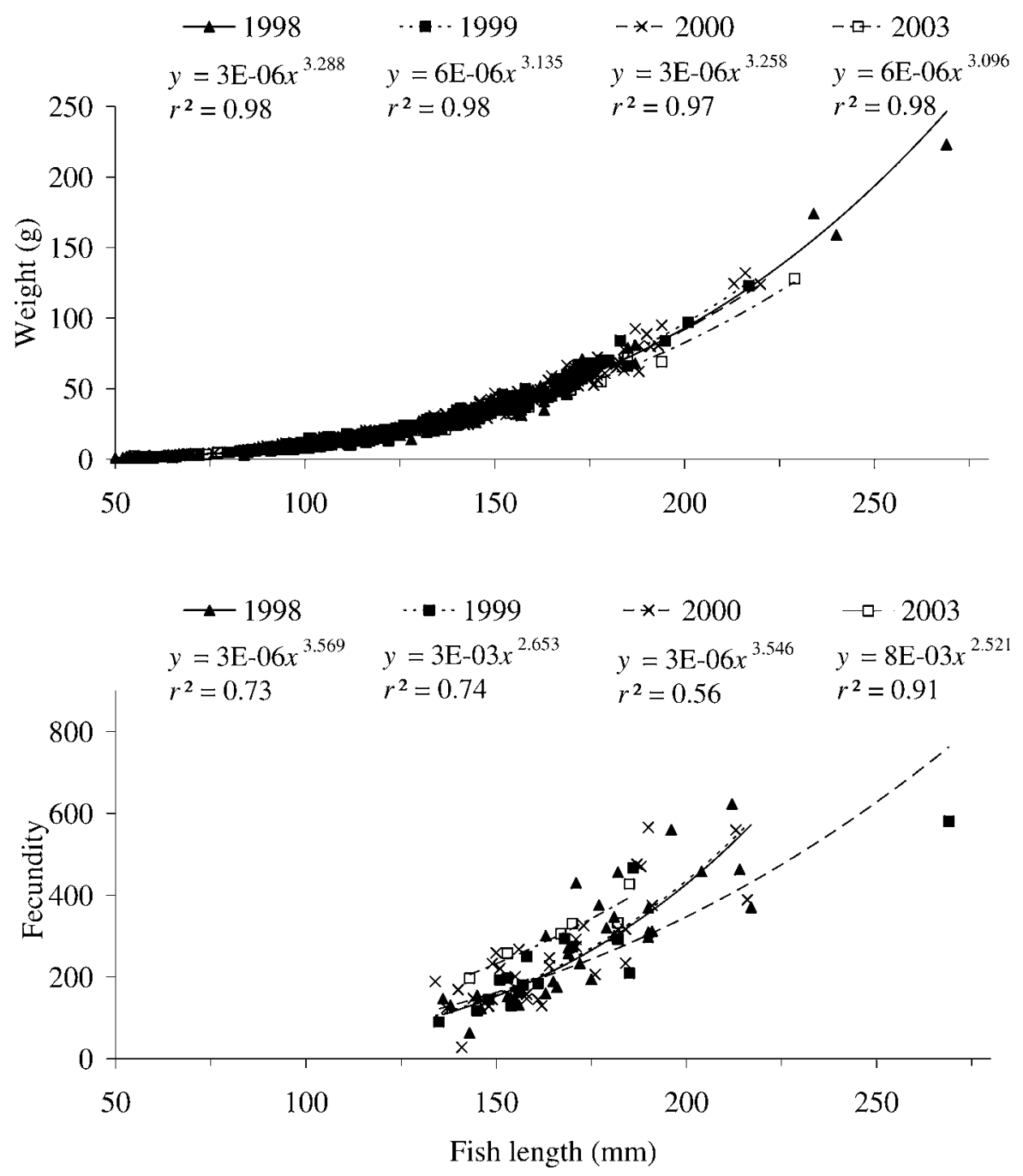

FIGURE 5.-Length-weight and length-fecundity relationships for nonnative brook trout removed by electrofishing in Pike's Fork, Idaho, during 1998-2000 and 2003. Length is total length (mm).

decreased during removal treatments); this may have been caused, in part, by yearly exposure of brook trout (i.e., those that escaped capture) to electrofishing, which can reduce growth rate (Dalbey et al. 1996; Thompson et al. 1997). Also, older fish might have allocated more energy into reproduction instead of growth, although we saw no indication of this in fecundity or maturity changes. A more likely explanation was given by McFadden (1977), who argued that the complexity of interactions between several compensatory response mechanisms may lead to the operation of only one or a few mechanisms under certain environmental conditions, preempting the operation of other mechanisms. The likely reduction in natural mortality may have sufficiently compensated for the increase in exploitation such that no other compensation was discernible in the population.

In addition to their compensatory abilities, brook trout can mature at an early age. Because age- 0 fish are difficult to capture with electrofishing gear and because age-1 fish were also not fully recruited to the electrofishing gear, it was difficult to remove all brook trout before they had the chance to spawn at least once. For example, the average length of age- 1 brook trout in Pike's Fork was $110 \mathrm{~mm}$ TL, and over half (54\%) of these fish were mature. Thus, if an individual brook trout escaped capture at age 0 and again at age 1 , the fish was likely to spawn that fall. 


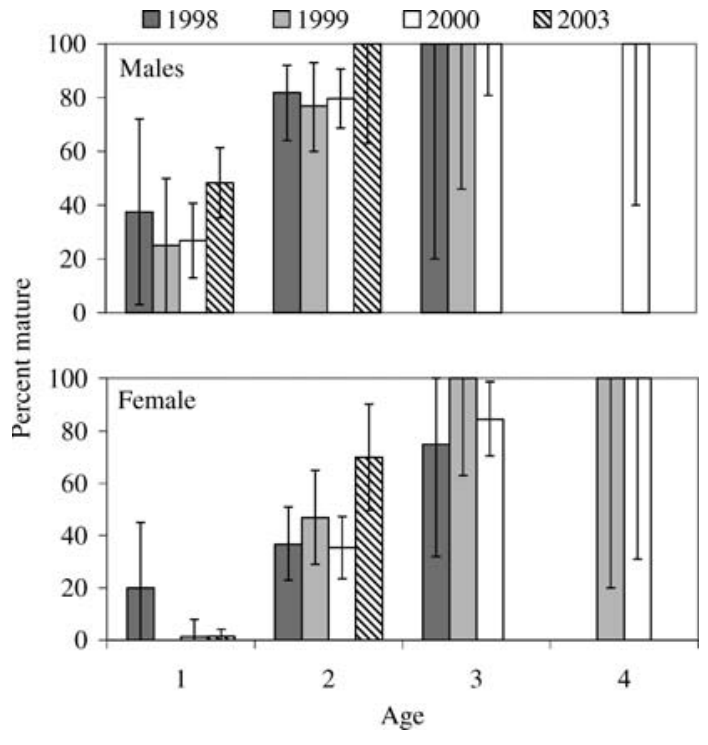

FIGURE 6.-Percentage $( \pm 95 \% \mathrm{CI})$ of nonnative brook trout males and females that were mature at each age in Pike's Fork, Idaho, during 1998-2003. Electrofishing removal of brook trout was conducted in all years except 2001 and 2002.

Previous studies (Riley and Fausch 1992; Peterson et al. 2004b; Rosenberger and Dunham 2005) have demonstrated that electrofishing removals can produce biased estimates of abundance because $\mathrm{CP}$ is lower than what is actually measured, producing abundance estimates that are too low, and in our case, removal efficiency estimates that were probably too high. We have no way of knowing true $\mathrm{CP}$ in this study. Peterson et al. (2004b) found that the removal method overestimated CP by $39 \%$ and underestimated abundance by $88 \%$, but they used straight DC to minimize fish injury, which most likely reduced capture efficiency. In this study, pulsed DC with relatively high voltage and pulse rates was used to maximize $\mathrm{CP}$, but nevertheless our associated removal efficiency estimates were probably still positively biased to some degree. If we drastically overestimated $\mathrm{CP}$, the actual number of brook trout in the stream would have been much higher than we estimated. In that event, the ineffectiveness of the project would reflect the inability to remove a large portion of the population more so than compensation by the remaining brook trout. In either case, the WAG removal effort was clearly unsuccessful, despite considerable exertions.

In addition to potentially biased estimates of abundance and CP, estimates of $S$ may have also been biased because we probably violated the catch curve assumptions of constant year-class strength and uniform survival rates over time (Ricker 1975).
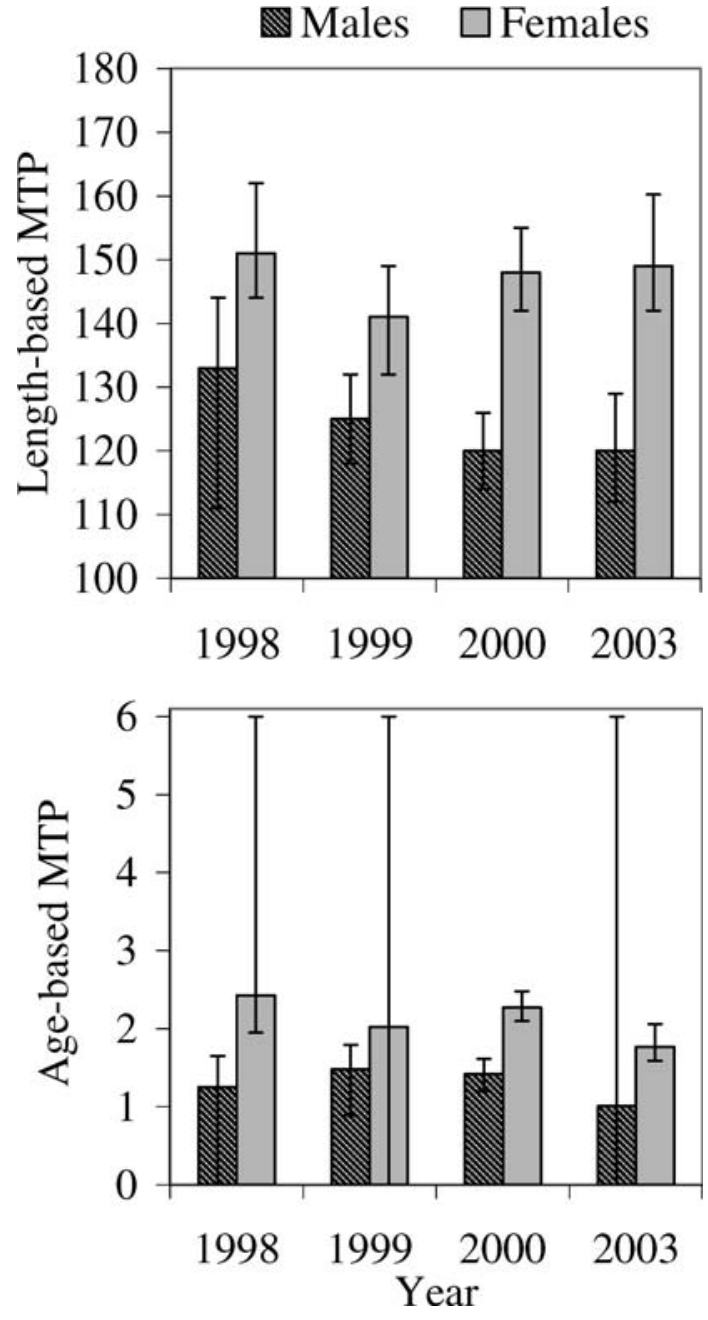

FIGURE 7.-Length-based (TL, mm) and age-based maturity transition points (MTPs; points where maturity probability = 0.50) ( $\pm 95 \% \mathrm{CI})$ calculated from logistic regression models for nonnative brook trout males and females in Pike's Fork, Idaho, during 1998-2003. Electrofishing removal of brook trout was conducted in all years except 2001 and 2002.

However, our conclusion that brook trout mortality was naturally very high in Pike's Fork was supported by (1) the low $S$ observed in 1998 before any bias could have occurred and (2) the agreement with cohort analysis. Such high mortality is common for brook trout populations in small streams (McFadden 1961; Phinney 1975).

Because we did not have a control stream, we cannot be certain that environmental conditions did not confound our results. For example, better conditions for growth, survival, or increased carrying capacity during the removal years could have produced the changes we have attributed to compensation. We could 
not incorporate a control stream in our study design because the criteria for such a control (i.e., a very small stream, but one from which we could sacrifice hundreds of brook trout for demographics comparisons with the treatment stream) necessarily excluded it as a true control (i.e., no manipulation). However, even if the changes in growth and survival we observed were caused by confounding factors, the fact remains that the brook trout population in Pike's Fork, through one or several mechanisms, withstood very high rates of exploitation with little (if any) long-term changes to the population.

Another potentially confounding factor is the possibility that some brook trout ascended the barrier. Although we never subsequently captured any of the brook trout marked in 1999 below the barrier, we only marked 50 fish and thus our ability to determine upstream movement was admittedly limited. We did capture two hatchery rainbow trout $(250$ and $300 \mathrm{~mm}$ TL) above the barrier in 2000, despite the fact that the nearest Idaho Department of Fish and Game (IDFG) fish stocking location is a few kilometers downstream (B. Turik, IDFG, personal communication). Unless these fish were illegally transported by an angler, they ascended the barrier. Adams et al. (2000) found that brook trout similar in size to those in Pike's Fork were able to ascend barrier heights of 0.5-1.2 m. Nevertheless, based on the barrier dimensions, we believe it is unlikely that many brook trout in Pike's Fork can ascend this barrier (see Kondratieff and Myrick 2006).

Other researchers have noted that brook trout can withstand intensive electrofishing eradication efforts (Thompson and Rahel 1996; Buktenica et al. 2000). Successful electrofishing removal projects have occurred, but usually in very narrow, short streams $(<3$ $\mathrm{km}$ ) with simple habitat that were electrofished several times per year, for several consecutive years, or both (Kulp and Moore 2000; Shepard et al. 2002). Whether or not eradication projects are worthwhile depends on the removal results, the amount of habitat restored to native fish assemblages, and the expenditure of time and money on the project. For the project we evaluated, a total of about 210 person-days was expended in 3 years during the electrofishing treatments alone. Although there were a number of volunteers, most person-days came from permanent or temporary employees of the organizations involved in the removal. We conservatively assumed an average salary (with benefits) of US $\$ 10$ per hour, an average field day of $10 \mathrm{~h}$, an average per diem of $\$ 20$ per day, $\$ 200$ per week for vehicle leasing and operation (one vehicle per two people), and $\$ 15,000$ for barrier installation. Using these figures, the unsuccessful eradication effort cost about $\$ 61,200$ overall or $\$ 7,846$ per kilometer of stream treated. Comparably, Shepard et al. (2002) estimated that $\$ 10,000$ per kilometer was spent to successfully remove brook trout and this estimate did not include the cost of the barrier.

Electrofishing as an eradication tool in Pike's Fork may have had more utility if the methodology of the more successful electrofishing removal projects had been followed, such as the use of effort with less intensity (spreading removal runs over the entire year), higher frequency (more treatments per year), and longer duration (more years of treatment). Nevertheless, we question whether use of electrofishing methods to eliminate brook trout populations will ever prove cost effective for an appreciable portion of waters in the western United States. Meyer et al. (2006) estimated that there were roughly 1.2 million brook trout present in the upper Snake River basin in Idaho. Based on results from this project, it might cost over $\$ 1$ million to perform electrofishing removals in only $5 \%$ of the current range of brook trout in the upper Snake River basin, and these removal efforts would probably not completely eliminate brook trout in treated areas.

In summary, the electrofishing removals in Pike's Fork were unsuccessful at removing brook trout and did not increase the number of native salmonids during the project. Brook trout populations in small streams appear to be well adapted for withstanding high rates of mortality, whether from natural causes, angling exploitation, or electrofishing removals. Except in very short, narrow streams with simple habitat, our results and the results of other studies suggest that electrofishing removals are unlikely to be successful in completely eradicating brook trout. Because brook trout clearly have the ability to outcompete many of the native salmonids in the western United States, a removal project that merely seeks to reduce brook trout density or that occurs over large stream lengths with little hope for total eradication would seem a costly but quixotic enterprise. Like Finlayson et al. (2005), we believe other methods (e.g., use of chemical treatments with rotenone and antimycin) would be more cost effective and successful at completely eradicating brook trout under most circumstances. Those who continue to use electrofishing for brook trout eradication may better illuminate the usefulness of the technique by quantitatively monitoring project cost effectiveness and fish population response.

\section{Acknowledgments}

The brook trout removal project was initiated and carried out by many people and organizations comprising the WAG, including Idaho Department of Environmental Quality; Idaho Department of Lands; U.S. Forest Service; U.S. Bureau of Reclamation; Boise Corp.; IDFG; and numerous volunteers. Greg 
Batts, Jeff Rice, Win Taylor, Nick Frohnauer, and John Cassinelli assisted with aging and demographics analyses. Chris Downs, Bob Danehy, Jim Capurso, Steve Yundt, Andrew Paul, Claire McGrath, Alan Byrne, James Peterson, and two anonymous reviewers provided comments and suggestions that greatly improved the manuscript. Funding for our evaluation of the WAG removal project was provided by the Bonneville Power Administration.

\section{References}

Adams, S. B., C. A. Frissell, and B. E. Rieman. 2000. Movements of nonnative brook trout in relation to stream channel slope. Transactions of the American Fisheries Society 129:623-638.

Allan, J. D., and A. S. Flecker. 1993. Biodiversity conservation in running waters: identifying the major factors that threaten destruction of riverine species and ecosystems. Bioscience 43:32-43.

Allen, M. S. 1997. Effects of variable recruitment on catchcurve analysis for crappie populations. North American Journal of Fisheries Management 17:202-205.

Beamish, R. J., and D. A. Fournier. 1981. A method for comparing the precision of a set of age determinations. Canadian Journal of Fisheries and Aquatic Sciences 38:982-983.

Beamish, R. J., and G. A. McFarlane. 1987. Current trends in age determination methodology. Pages 15-42 in R. C. Summerfelt and G. E. Hall, editors. Age and growth of fish. Iowa State University Press, Ames.

Buktenica, M. W., B. D. Mahoney, S. F. Girdner, and G. L. Larson. 2000. Response of a resident bull trout population to nine years of brook trout removal, Crater Lake National Park, Oregon. Pages 127-132 in D. Schill, S. Moore, P. Byorth, and B. Hamre, editors. Wild trout VII: management in the new millennium, are we ready? Yellowstone National Park, Wyoming.

Cooper, E. L., J. A. Boccardy, and J. K. Anderson. 1962. Growth rate of brook trout at different population densities in a small infertile stream. Progressive FishCulturist 24:74-80.

Dalbey, S. R., T. E. McMahon, and W. Fredenberg. 1996. Effect of electrofishing pulse shape and electrofishinginduced spinal injury on long-term growth and survival of wild rainbow trout. North American Journal of Fisheries Management 16:560-569.

DeVries, D., and R. Frie. 1996. Determination of age and growth. Pages 483-512 in B. R. Murphy and D. W. Willis, editors. Fisheries Techniques, 2nd edition. American Fisheries Society, Bethesda, Maryland.

Donald, D. B., and D. J. Alger. 1989. Evaluation of exploitation as a means of improving growth in a stunted population of brook trout. North American Journal of Fisheries Management 9:177-183.

Dunham, J. B., S. B. Adams, R. E. Schroeter, and D. C. Novinger. 2002. Alien invasions in aquatic ecosystems: toward an understanding of brook trout invasions and potential impacts on inland cutthroat trout in western North America. Reviews in Fish Biology and Fisheries 12:373-391.
Fausch, K. D. 1988. Test of competition between native and introduced salmonids in streams: what have we learned? Canadian Journal of Fisheries and Aquatic Sciences 45:2238-2246.

Fausch, K. D. 1989. Do gradient and temperature affect distribution of, and interactions between brook char and other salmonids in streams? Physiology and Ecology Japan, Special Volume 1:303-322.

Finlayson, B., W. Somer, D. Duffield, D. Propst, C. Mellison, T. Pettengill, H. Sexauer, T. Nesler, S. Gurtin, J. Elliot, F. Partridge, and D. Skaar. 2005. Native inland trout restoration on national forests in the western United States: time for improvement? Fisheries 30(5):10-19.

Fleiss, J. L. 1981. Statistical methods for rates and proportions. Wiley, New York.

Fuller, P. L., L. G. Nico, and J. D. Williams. 1999. Nonindigenous fishes introduced into inland water of the United States. American Fisheries Society, Special Publication 27, Bethesda, Maryland.

Gresswell, R. E. 1991. Use of antimycin for removal of brook trout from a tributary of Yellowstone Lake. North American Journal of Fisheries Management 11:83-90.

Griffith, J. S. 1988. Review of competition between cutthroat trout and other salmonids. Pages 134-140 in R. E. Gresswell, editor. Status and management of interior stocks of cutthroat trout. American Fisheries Society, Symposium 4, Bethesda, Maryland.

Jensen, A. L. 1971. Response of brook trout (Salvelinus fontinalis) populations to a fishery. Journal of the Fisheries Research Board of Canada 28:458-460.

Jones, M. L., and J. D. Stockwell. 1995. A rapid assessment procedure for the enumeration of salmonine populations in streams. North American Journal of Fisheries Management 15:551-562.

Kondratieff, M. C., and C. A. Myrick. 2006. How high can brook trout jump? A laboratory evaluation of brook trout jumping performance. Transactions of the American Fisheries Society 135(2):361-370.

Krueger, C. C., and B. May. 1991. Ecological and genetic effects of salmonid introductions in North America. Canadian Journal of Fisheries and Aquatic Sciences 48:66-77.

Kruse, C. G., W. A. Hubert, and F. J. Rahel. 1998. Single-pass electrofishing predicts trout abundance in mountain streams with sparse habitat. North American Journal of Fisheries Management 18:940-946.

Kulp, M. A., and S. E. Moore. 2000. Multiple electrofishing removals for eliminating rainbow trout in a small southern Appalachian stream. North American Journal of Fisheries Management 20:259-266.

Larson, G. L., S. E. Moore, and D. C. Lee. 1986. Angling and electrofishing for removing nonnative rainbow trout from a stream in a national park. North American Journal of Fisheries Management 6:580-585.

Levin, P. S., S. Achord, B. E. Feist, and R. W. Zabel. 2002. Non-indigenous brook trout and the demise of Pacific salmon: a forgotten threat? Proceedings of the Royal Society of London 269: 1663:1670.

Lobón-Cerviá, J., and C. Utrilla. 1993. A simple model to determine stream trout (Salmo trutta L.) densities based on one removal with electrofishing. Fisheries Research 15:369-378. 
McFadden, J. T. 1961. A population study of the brook trout, Salvelinus fontinalis. Wildlife Monographs 7:1-73.

McFadden, J. T. 1976. Environmental impact assessment for fish populations. Pages 89-137 in P. Gustafson, editor. The biological significance of environmental impacts. University of Michigan, Ann Arbor.

McFadden, J. T. 1977. An argument supporting the reality of compensation in fish populations and a plea to let them exercise it. Pages 153-183 in W. Van Winkle, editor. Proceedings of the conference on assessing the effects of power-plant-induced mortality on fish populations. Pergamon, Tarrytown, New York.

Meronek, T. G., P. M. Bouchard, E. R. Buckner, T. M. Burri, K. K. Demmerly, D. C. Hatleli, R. A. Klumb, S. H. Schmidt, and D. W. Coble. 1996. A review of fish control projects. North American Journal of Fisheries Management 16:63-74.

Meyer, K. A., D. J. Schill, F. S. Elle, and J. A. Lamansky. 2003. Reproductive demographics and factors that influence length at sexual maturity of Yellowstone cutthroat trout in Idaho. Transactions of the American Fisheries Society 132:183-195.

Meyer, K. A., D. J. Schill, J. A. Lamansky Jr., M. R. Campbell, and C. C. Kozfkay. 2006. Status of Yellowstone cutthroat trout in Idaho. Transactions of the American Fisheries Society 135:1329-1347.

Moore, S. E., B. Ridley, and G. L. Larson. 1983. Standing crops of brook trout concurrent with removal of rainbow trout from selected streams in Great Smoky Mountains National Park. North American Journal of Fisheries Management 3:72-80.

Moyle, P. B. 1986. Fish introductions into North America: patterns and ecological impact. Pages 27-43 in H. A. Mooney and J. A. Drake, editors. Ecology of biological invasions in North America and Hawaii. SpringerVerlag, New York.

Paul, A. J., J. R. Post, and J. D. Stelfox. 2003. Can anglers influence the abundance of native and nonnative salmonids in a stream from the Canadian Rocky Mountains? North American Journal of Fisheries Management 23:109-119.

Peterson, D. P., K. D. Fausch, and G. C. White. 2004a. Population ecology of an invasion: effects of brook trout on native cutthroat trout. Ecological Applications 14:754-772.

Peterson, J. T., R. F. Thurow, and J. W. Guzevich. 2004b. An evaluation of multipass electrofishing for estimating the abundance of stream-dwelling salmonids. Transactions of the American Fisheries Society 133:462-475.

Phinney, D. E. 1975. Repopulation of an eradicated stream section by brook trout. Transactions of the American Fisheries Society 104:685-687.

Rahel, F. J. 2000. Homogenization of fish fauna across the United States. Science 288(5467):854-856.

Reynolds, J. B. 1996. Electrofishing. Pages 221-254 in
B. Murphy and D. Willis, editors. Fisheries techniques, 2nd edition. American Fisheries Society, Bethesda, Maryland.

Rice, W. R. 1989. Analyzing tables of statistical tests. Evolution 43:223-225.

Ricker, W. E. 1975. Computation and interpretation of biological statistics of fish populations. Fisheries Research Board of Canada Bulletin 191.

Riley, S. C., and K. D. Fausch. 1992. Underestimation of trout population size by maximum-likelihood removal estimates in small streams. North American Journal of Fisheries Management 12:768-776.

Robson, D. S., and D. G. Chapman. 1961. Catch curves and mortality rates. Transactions of the American Fisheries Society 90:181-189.

Roff, D. A. 1992. The evolution of life histories: theory and analysis. Chapman and Hall, New York.

Rosenberger, A. E., and J. B. Dunham. 2005. Validation of abundance estimates from mark-recapture and removal techniques for rainbow trout by electrofishing in small streams. North American Journal of Fisheries Management 25:1395-1410.

Scheaffer, R. L., W. Mendenhall, and L. Ott. 1996. Elementary survey sampling, 5th edition. Duxbury Press, Belmont, California.

Shepard, B. B., R. Spoon, and L. Nelson. 2002. A native westslope cutthroat trout population responds positively after brook trout removal and habitat restoration. Intermountain Journal of Science 8:191-211.

Strange, R. J. 1996. Field examination of fishes. Pages 433446 in B. R. Murphy and D. W. Willis, editors. Fisheries Techniques, 2nd edition. American Fisheries Society, Bethesda, Maryland.

Thompson, K. G., E. P. Bergersen, and R. B. Nehring. 1997. Injuries to brown trout and rainbow trout induced by capture with pulsed direct current. North American Journal of Fisheries Management 17:141-153.

Thompson, P. D., and F. J. Rahel. 1996. Evaluation of depletion-removal electrofishing of brook trout in small Rocky Mountain streams. North American Journal of Fisheries Management 16:332-339.

Van Deventer, J., and W. S. Platts. 1989. Microcomputer software system for generating population statistics from electrofishing data-user's guide for MicroFish 3.0. U.S. Forest Service General Technical Report INT-254.

Young, M. K. 1995. Conservation assessment for inland cutthroat trout. U.S. Forest Service General Technical Report RM-GTR-256.

Young, M. K., B. K. Micek, and M. Rathbun. 2003. Probable pheromonal attraction of sexually mature brook trout to mature male conspecifics. North American Journal of Fisheries Management 23:276-282.

Zar, J. H. 1996. Biostatistical analysis, 3rd edition. Prentice Hall, Upper Saddle River, New Jersey. 